\title{
Booklet content validation on excess weight for adults with hypertension
}

\author{
Validação de conteúdo de cartilha sobre excesso ponderal para adultos com hipertensão \\ Validación de contenido de cartilla sobre exceso ponderal para adultos con hipertensión
}

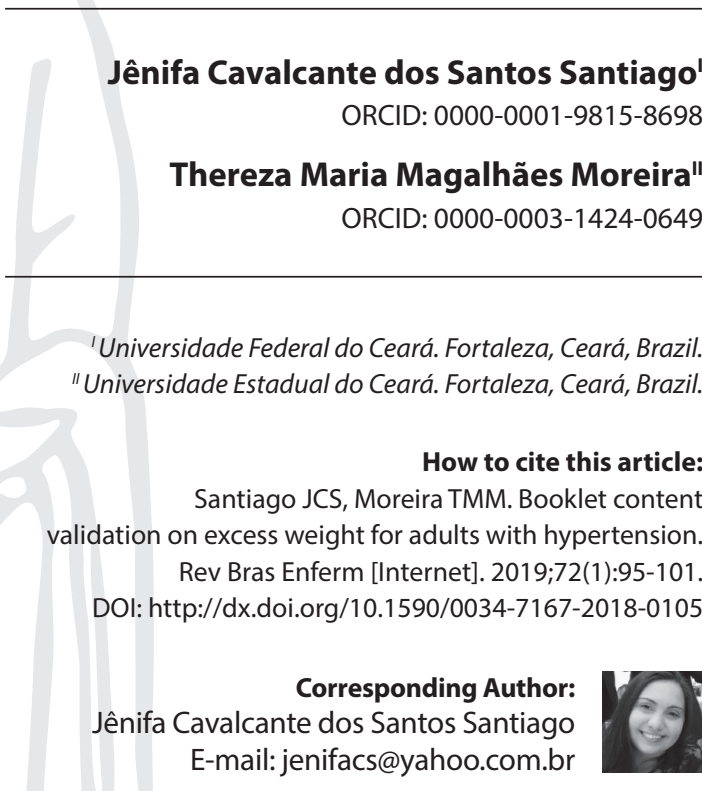

Submission: 03-04-2018

Approval: 07-17-2018

\begin{abstract}
Objective: To validate the content and appearance of an educational booklet about excess weight for adults with hypertension. Method: Methodological study in which an educational booklet was developed from theoretical material on hypertension, chronic diseases and obesity, as well as guiding points for the clinical practice of the nurse in the care of young adults with excess weight and based on the Transtheoretical Model. Twenty-one specialists participated in the validation of content and appearance, being 9 teachers, 7 technicians and 5 designers. Results: The Global Content Validity Index was 0.78 and the material was considered appropriate or superior. The experts suggested adjustments, incorporated into the material for print production of the final version. Conclusion: The educational booklet for people with hypertension and excess weight was considered valid regarding content and appearance.
\end{abstract}

Descriptors: Educational Technology; Overweight; Obesity; Hypertension; Validation Studies.

\section{RESUMO}

Objetivo: Validar o conteúdo e aparência de uma cartilha educativa sobre excesso ponderal para adultos com hipertensão arterial. Método: Tratou-se de estudo metodológico em que se desenvolveu uma cartilha educativa a partir de material teórico sobre hipertensão, doenças crônicas e obesidade, bem como pontos norteadores para a prática clínica do enfermeiro no cuidado ao adulto jovem com excesso ponderal e com base no Modelo Transteorético. Participaram da validação de conteúdo e aparência 21 especialistas, sendo 9 docentes, 7 técnicos e 5 designers. Resultados: O Índice de Validade de Conteúdo global foi de 0,78 e o material foi considerado adequado ou superior. Os especialistas sugeriram ajustes, incorporados ao material para produção impressa da versão final. Conclusão: A cartilha educativa para pessoas com hipertensão e excesso ponderal foi considerada válida quanto ao conteúdo e aparência.

Descritores: Tecnologia Educacional; Sobrepeso; Obesidade; Hipertensão; Estudos de Validação.

\section{RESUMEN}

Objetivo: Validar el contenido y apariencia de una cartilla educativa sobre exceso ponderal para adultos con hipertensión arterial. Método: Se trató de un estudio metodológico en el que se desarrolló una cartilla educativa a partir de material teórico sobre hipertensión, enfermedades crónicas y obesidad, así como puntos orientadores para la práctica clínica del enfermero en el cuidado al adulto joven con exceso ponderal y con base en el Modelo Transteorético. Participaron de la validación de contenido y apariencia 21 especialistas, siendo 9 docentes, 7 técnicos y 5 designers. Resultados: El Índice de Validez de Contenido global fue de 0,78 y el material fue considerado adecuado o superior. Los expertos sugirieron ajustes, incorporados al material para producción impresa de la versión final. Conclusión: La cartilla educativa para personas con hipertensión y exceso ponderal fue considerada válida en cuanto al contenido y apariencia.

Descriptores: Tecnología Educacional; Sobrepeso; Obesidad; Hipertensión; Estudios de Validación. 


\section{INTRODUCTION}

Hypertension is a multifactorial condition with high global prevalence ${ }^{(1)}$. It represents the main risk factor for cardiovascular complications, such as stroke, acute myocardial infarction, chronic kidney disease, as well as atherosclerotic diseases, especially when associated with overweight. The non-control of these cardiovascular risk factors reflects directly in the budget of the Ministries of Health, Social Security and Economy ${ }^{(2-4)}$.

Considering the goal of the World Health Organization (WHO) to reduce Noncommunicable Diseases (NCD) mortality by $2 \%$ annually ${ }^{(5)}$ and the existence of scientific evidence that preventive actions are effective in the context of primary health, there is a need for global policy action to reduce cardiovascular risk, implementing measures at the community level, with cost-effective interventions. This includes teaching activities and updating of the clientele, implemented by health professionals, that directly influence adherence to healthy eating and practice of regular physical activity ${ }^{(2)}$.

The complex setting in which the individual with hypertension and excess weight is inserted presents challenges for the Brazilian Unified Health System (SUS - Sistema Único de Saúde) and for health professionals, above all, for the nurse, who is closer to the daily life of his patients. Thus, interventions performed by nurses to reverse excess weight in the adult with hypertension need to consider the different conceptions about diet, physical activity, body and health when craving the change in lifestyle for this clientele.

It is said that changes follow a sequence in which the individual moves on to the next stage if the characteristics of that stage are already incorporated. The sequence includes: pre-contemplation, contemplation, preparation, action and maintenance ${ }^{(6)}$. Therefore, the nurse, when conducting health education with the adult hypertensive population, has the challenge of not only informing about health, but also sensitizing the clientele to the need for change, aiming to provide progress in the stage of behavior change. One of the means of making this awareness possible is to use educational technologies.

The effectiveness of educational health interventions is influenced by several variables, among them the availability of materials that can be used as a didactic resource. When considering that the health orientation about the excess weight in people with hypertension can be realized with the use of educational technologies constructed from scientific evidence, it is observed the pertinence of constructing educational materials of good quality and with contents adequate to make feasible the understanding of information by the target audience ${ }^{(7)}$. Such materials are useful resources and can be used to contribute to the process of health education.

It is stated that booklet, as health technology, is shown to be a tool for health promotion and facilitator of the educational process in health, contributing to actions that recognize the true need of the applied population, be it patient, family, or health professionals ${ }^{(8)}$. Thus, it was questioned: Is the content and appearance of an educational booklet constructed with information about excess weight for adults with hypertension valid?

\section{OBJECTIVE}

This study aims to validate the content and appearance of an educational booklet about excess weight for adults with hypertension.

\section{METHOD}

\section{Ethical aspects}

This study respected the ethical and legal precepts involving human beings, having approval in Ethics and Research Committee, confidentiality of identification and reading and application of Free and Informed Consent Term to individuals who accepted to participate in the study.

\section{Design, place of study and period}

This is a methodological study, since it refers to the validation of a tool as a research technique that can be used by other researcher ${ }^{(9)}$.

Initially, a general summary of what would be addressed in the educational booklet was drawn up, based on the literature on excess weight. The literature used consisted of the notebooks 35,37 and 38 - Strategies for the care of the person with chronic disease, hypertension and obesity, respectively ${ }^{(10-12)}$, as well as the Brazilian Guidelines for Obesity (Diretrizes Brasileiras de Obesidade) ${ }^{(13)}$ and the VII Brazilian Guidelines for Hypertension (VII Diretrizes Brasileiras de Hipertensão) $)^{(14)}$. In addition, we considered the guiding points listed for the clinical practice of nurses in the care of young adults with and without excess weight ${ }^{(15)}$. Chart 1 presents these points.

After reading the material that subsidized the creation of the booklet, a script of content was elaborated to be approached, in a logical sequence, with suggestions of illustrations that best represented the content on canvas. The theoretical model related to the individual's willingness to adhere to change was used as an ally in the elaboration of the educational material, the Transtheorical Model, also known as the model of the stages of readiness for behavior change ${ }^{(6)}$.

Chart 1 - Guiding points for the clinical practice of nurses in the care of young adults with and without excess weight ${ }^{(15)}$

1. Considering that obesity is a multifactorial and heterogeneous disease involving biological, historical, ecological, economic, social, cultural and political factors, whose causes are not only individual but also environmental and social;

2. It is incumbent on the nurse to perform the nursing consultation, monitor the anthropometric data and request complementary examinations to evaluate the cases of risks and, when necessary, refer to a specialized professional, in an interdisciplinary care perspective;

3. The nurse must identify, in partnership with the patient, which factors contributed, contribute or contribute to the excess weight picture, from the perspective of food, social and sports behavior;

4. Together, the nurse and the patient should seek strategies to overcome these factors;

5. For environmental and social factors, on which the individual has little or no capacity for interference, nurses and patients should use the proposals offered by public health policies and plans related to the clinical condition;

6. When excess weight is already present, the nurse and the patient should seek methods that minimize the risks of associated comorbidities;

7. The nurse must rely on the collaboration of other health professionals to offer comprehensive and interdisciplinary care to the adult;

8. All intervening factors identified must be worked by the nurse in the strategy of health promotion to the adult who has not yet developed excess weight, with educational practices in health;

9. Finally, the nurse must always seek to be updated in terms of surveys and research related to the clinical care that he provides, as well as conducting research that brings viable contributions to implementation. 
This model uses the construction of phases of change, that is, instead of modifying the behaviors considered inappropriate in a direct and abrupt way, the person does it in stages, in the context of a decisional balance, seeking self-efficacy in the process of change. The stages of change pass consecutively through the stages of preconception, contemplation, preparation, action and maintenance, including the temporal and motivational aspect for change. The changes must occur in the intention, attitude and behavior for the individual to pass from one phase to another. Thus, instead of seeking to know the reasons for the changes, the model seeks to indicate how they occur using the stages and processes of behavior change as indicators ${ }^{(6)}$.

The ideas were organized in slides using Microsoft Power Point Software 2010 and sent to a technical professional to draw up the graphics and layout. To prepare the art, the professional received guidelines on the type of engraving, according to the theoretical content of the booklet, previously elaborated by the researcher, constructing attractive illustrations and easy to understand. A character was used that presented doubts and yearnings about the various subjects that permeate hypertension as a clinical condition, aiming at the facilitation and understanding of the teachings, even for people with reading difficulties.

With illustrations in hand, the pages were formatted, configured and diagrammed. The graphic designer then elaborated the art and it was submitted to the validation by specialists.

\section{Population or sample; criteria of inclusion and exclusion}

For the selection of the judges, the formula was adopted that considers the final proportion of the subjects with respect to the determined dichotomous variable and the maximum acceptable difference of this proportion ${ }^{(16)}: \mathrm{n}=\mathrm{Za}^{2}$. P . (1-P) / $\mathrm{d}^{2}$, where: Za: Refers to the level of confidence (95\% was agreed); P: Proportion of individuals who agree with the pertinence of the items; $d$ : Difference of the proportion considered acceptable. Thus, for the establishment of sample size in the present study, the following statistical criteria were adopted: Minimum ratio of $85 \%$ agreement with respect to the pertinence of each evaluated component and $15 \%$ difference in concordance, including a range of $70 \%$ to $100 \%$ in said agreement. At the end, the calculation was determined by $\mathrm{n}=(1.962 .0 .85 .0 .15) / 0.152$, obtaining a sample of 22 judges; however, in order to avoid a tie, it was decided to work with 21 judges, distributed in three groups with odd numbers in each group: Group A, with nine researchers with experience in booklet themes; Group B, seven nurses with assistance experience to the target clientele of educational material and Group C, five professionals with experience in design or marketing. It was not possible to adopt seven judges in each group, due to the difficulty of reaching the $n$ between the judges of design and marketing, and therefore, there was also a greater number of judges of content, besides the undeniable importance of this group.

Group A and B specialists were selected, considering a minimum score of five points, according to adapted criteria ${ }^{(17)}$, which included academic production, publications, participation in research groups, examinations, teaching experience, clinical experience and guidance on the subjects involved in the booklet. The experts of Group C were recruited by the snowball sampling, also considering the adapted criteria, replacing the theme of the booklet by thematic design and/or marketing.

\section{Study protocol}

To evaluate the educational material by the content judges and technicians was carried out adaptation of a tool used to validate an educational technology for the self-care of the woman in the rehabilitation of the mastectomy ${ }^{(18)}$. This contained the participant's profession, time and area of action, degree and scientific production. It consisted of closed questions regarding the information contained in the booklet regarding: objectives, relevance, structure and presentation. It also had a space for suggestions.

The second tool, designed for judges in the sector of Design and Marketing, was elaborated, based on the American tool for evaluation of the difficulty and convenience of educational materials, called Suitability Assessment of Materials (SAM), translated into Portuguese ${ }^{(19)}$.

\section{Results analysis and statistics}

The Content Validity Index (CVI) calculation was applied in the first two groups, considering the proportion of responses 3 or 4 divided by the total responses. A minimum value for $\mathrm{CVI}$ is recommended, which is $0.78^{(9)}$, adopted in this study. The binomial test was used to estimate the statistical reliability of the CVI, considering a $p$ value $<0.05$.

In the SAM tool there is a list to check attributes related to content, writing style, appearance, motivation and cultural appropriateness of the educational material. For each item in the list there are options of scores: 2 - adequate, 1 - partially adequate and 0 - inadequate. The calculation of the total adequacy score is made from the sum of the scores obtained, divided by the maximum total score ( 13 items $=26$ scores) and multiplied by 100 , to transform it into a percentage and the interpretation is as follows: $70-100 \%$ (Top material), $40-69 \%$ (Suitable material) or 0-39\% (Inappropriate material) ${ }^{(19)}$.

\section{RESULTS}

The initial version of the educational booklet entitled "PRONTITUDE: feeding and physical activity in hypertensive adult" consisted of 32 pages, double-sided, A4 folded in half, booklet format, colored, Berlin Sans FB Demi font, sizes 12 and 14, with cover, presentation, summary and the items: 1- Does my excess weight influence my pressure?; 2 - What are the advantages of changing my lifestyle?; 3 - Do l eat too much?; 4 - Can I drink water during meals?; 5 - Can I eat whenever I feel like it? 6 - What are healthy foods and how should my meals be?; 7 - Do I need to do physical activity? 8 -Write your BMI here; 9 - Annotations; and 10 - References.

Concerning the sociodemographic characterization of the specialists who contributed to the validation of the material produced, there was a predominance of females in Groups A and B ( 88.9 and $100 \%$, respectively), except in Group C ( $80 \%$ of males); nurses (Group A: 88.9\% and Group B: 100\%) and graphic designer (Group C: $40 \%$ ); with a training time of more than 10 years (Group A: $88.9 \%$ and Group B: $100 \%$ ) and working time in the area of more 
than six years (Group A: 66.7\% and Group B: 100\%), doctors (Group A: $77.8 \%$ ) and masters (Group B: $71.4 \%$ and Group C: $80 \%$ ).

Table 1 presents the results of the evaluation tool used by the 16 specialists from Groups A (nine judges) and B (seven judges).

The global Content Validity Index was 0.78. The items used for the Content Validity Index were divided into three categories: 1 objectives; 2-structure and presentation; and 3 - relevance. Among the 18 items evaluated, only four did not reach the minimum CVI adopted in this study, which was $0.78^{(9)}$.

The items that received scores below the recommended level were: "messages are presented in a clear and objective way", "the material is appropriate to the socio-cultural level of the proposed target audience", "illustrations are expressive and sufficient" and "the material addresses the issues necessary to prevent complications".

The teaching and assistance specialists used the space for comments and suggested changes in the booklet. Thus, after analyzing the evaluations of each specialist, the changes were compiled and new contact was made with the graphic designer to incorporate the changes to the material.

The five professionals with experience in design or marketing evaluated the booklet through the translated SAM tool ${ }^{(19)}$ and their answers are in Table 2 below.

According to table 2, it was observed that no expert evaluated the items as inappropriate, but a specialist questioned whether the cover attracted attention and portrayed the purpose of the material. However, written considerations were made and these were incorporated into the list of adjustments requested by the teaching and care specialists. Considering the evaluation performed by the technical experts and the total score calculated for the SAM tool, the booklet was considered adequate (20\%) or higher (80\%), and was approved by all design/marketing judges.

With the evaluations carried out by the teaching, care and design/marketing specialists, the items were corrected in the booklet, contemplating the suggestions that included items with CVI below 0.78 .

Suggestions from the experts of the three groups are set out in Chart 2.

After all the corrections, the final version of the booklet was sent back to three teaching specialists chosen because they were those who had the lowest CVI in their evaluation of the booklet, as directed ${ }^{(20)}$, who reassessed the material and considered it suitable for use, all items with CVI being equal to or greater than 0.78. The booklet was not forwarded to the design/marketing specialists because, in the first evaluation, everyone approved the booklet, considering it as appropriate or superior.

The final version of the booklet remained with 32 pages, being now entitled "Food and physical activity in the adult with hypertension and overweight: willing to change?", Booklet format, with A4 folded in half, printed on couché paper and bound, with cover, presentation, catalytic record, summary and the items: I Does my excess weight influence my pressure?; II - What are the advantages of changing my lifestyle?; III - Do I eat right? IV - Do I need to do physical activity? My space, Notes and References, plus the message on the back: "More important than the will to change is the courage to begin".

Table 1 - Distribution of the Content Validity Indexes of educational booklet elements, according to the analyzes of the teaching and assistance specialists, Fortaleza, Ceará State, Brazil, 2018

Itens

CVI value*

Objectives

They are consistent with the needs of patients with hypertension, referring to health education in the context of excess weight.

Promote progress in the readiness stage to change physical activity and eating habits.

May circulate in the scientific environment in the area of excess weight and hypertension.

The educational material is suitable for counseling hypertensive patients about modifiable risk factors for excess weight.

Messages are presented in a clear and objective way.

The information presented is scientifically correct.

There is a logical sequence of proposed content.

The material is appropriate to the socio-cultural level of the proposed target audience.

The information is well structured in agreement and spelling.

The writing style corresponds to the knowledge level of the Target Audience.

Cover, back cover, acknowledgment and/or presentation information is consistent.

Illustrations are expressive and sufficient.

The number of pages is adequate.

The size of the title and topics is adequate.

Relevance

The themes portray key aspects that should be reinforced.

The material proposes to the patient to acquire knowledge about modifiable risk factors for excess weight (physical activity and feeding).

The material addresses the issues necessary to prevent complications.

It is suitable for use by any health professional in their educational activities.
0.88

0.81

0.94

0.81

0.004

0.047

0.001

0.63

0.94

0.81

0.69

0.81

0.81

0.81

0.56

0.88

0.81

0.021

0.454

0.001

0.047

0.210

0.021

0.021

0.021

0.804

0.004

0.021

0.88

0.81

0.004

$0.69-0.210$

$0.81 \quad 0.047$ 
Items evaluated through Suitability Assessment of Materials, according to domains.

\begin{tabular}{|c|c|c|}
\hline \multicolumn{2}{|c|}{$\begin{array}{c}\text { Design/Marketing } \\
\text { judges that approved } \\
\text { the booklet }\end{array}$} & \multirow{2}{*}{$\begin{array}{c}\text { Design/Marketing } \\
\text { judges that did } \\
\text { not approve the } \\
\text { booklet }\end{array}$} \\
\hline $\mathbf{A}$ & $\mathrm{PA}^{* *}$ & \\
\hline
\end{tabular}

The objective is clear, facilitating the prompt understanding of the material.

The content addresses behavioral information that helps in readiness for changing eating

을 habits and physical activity in hypertensive adults.

The proposal of the material is limited to the objectives, so that the viewer can reasonably understand in the minimum time necessary.

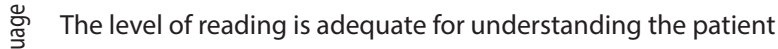

宅 Conversation style makes text easier to understand.

The vocabulary uses common words.

O. The cover draws attention and portrays the purpose of the material.

政

.

음 $\frac{2}{5}$ Interaction of the text and/or figures occurs with the reader, leading them to solve problems, make choices and/or demonstrate skills.

$\begin{array}{lll}4 & 1 & 0 \\ 4 & 1 & 0 \\ 5 & 0 & 0 \\ 5 & 0 & 0 \\ 3 & 2 & 0 \\ 5 & 0 & 0 \\ 4 & 1 & 0 \\ 4 & 1 & 0 \\ 3 & 2 & 0 \\ & & \\ 4 & 1 & 0 \\ 5 & 0 & 0 \\ 3 & 2 & 0 \\ 5 & 0 & \end{array}$

0

들 Desired patterns of behavior are modeled or well demonstrated.

There is the motivation to change behavior, that is, people are motivated to change because they believe that the tasks and behaviors are feasible.

एक The material is culturally appropriate to the logic, language and experience of the target audience.

It presents culturally appropriate images and examples.

Note: $A^{*}=$ Appropriate and $P A^{* *}=$ Partially Appropriate, according to the classification of the items of the SAM tool.

Chart 2 - List of changes to be incorporated in the educational booklet under construction, Fortaleza, Ceará, Brazil, 2018

\begin{tabular}{|c|c|}
\hline Cover & $\begin{array}{l}\text { Change the drawing and title. Make the title more exciting and the image easier to understand. } \\
\text { Add technical sheet. }\end{array}$ \\
\hline Presentation & Reduce and simplify the text. Take away that is the result of a doctoral thesis. \\
\hline Page 4 & $\begin{array}{l}\text { Side A: Color the image. Put the office in real-life color. The health professional's shirt should not be blue, as it is already the background color } \\
\text { of the image. Take two consecutive questions. The health professional's speech should answer the question of the character. }\end{array}$ \\
\hline Page 8 & $\begin{array}{l}\text { Side B: Color the fruits. Change the color that highlights the text at the bottom of the B side, to another color that is not blue. } \\
\text { Swap side A with side B, so the character's question comes first. When talking about economics, bring the character doing something } \\
\text { healthy that does not spend money. Withdraw satire, replace with motivational phrases "I can"... }\end{array}$ \\
\hline Page 10 & $\begin{array}{l}\text { The figure in graph format is difficult to understand. Make it clearer. } \\
\text { Replace mirror image with healthy-looking character image. }\end{array}$ \\
\hline Page 12 & $\begin{array}{l}\text { Leave the spoon drawing without the beans and rice as it is not clear. } \\
\text { The image of the stomach is not clear. Draw on the character. Bring the next page to the same page, because they deal with the same subject. } \\
\text { Remove the question from the character. Replace character's ironic speech with enthusiasm. }\end{array}$ \\
\hline Page 13 & $\begin{array}{l}\text { Add a page explaining how meals should be. } \\
\text { Replace the satire speech of the character with a speech of excitement. }\end{array}$ \\
\hline Page 16 & $\begin{array}{l}\text { Side A: substitute the figure "light" for milk figures and others cited in the text, highlighting the term "light" and/or "low fat" on the } \\
\text { label of the products designed, so the patient draws attention to the information on the label when to buy. }\end{array}$ \\
\hline Page 17 & $\begin{array}{l}\text { The text on side A should be corrected "Milk and its byproducts are also important. They are the major suppliers of calcium to our body } \\
\text { and can reduce the risk of osteoporosis, that disease in which our bones break easily". } \\
\text { Put X on top of the greasy barbecue picture. Replace the negative speech of the character with speech of excitement. Change the } \\
\text { background color to light color. } \\
\text { Delete pages } 18 \text { and } 19 \text { and highlight the importance of fruits and vegetables. }\end{array}$ \\
\hline Page 21 & $\begin{array}{l}\text { Add speech of the character demonstrating mood with the information. } \\
\text { Do not bring two consecutive questions }\end{array}$ \\
\hline Page 25 & $\begin{array}{l}\text { Delete next page. } \\
\text { Change the last speech of the character to speak of excitement, willingness to change. }\end{array}$ \\
\hline
\end{tabular}




\begin{tabular}{|l|l|}
\hline Page 29 & Bring talking about the character excited to make more physical movement. \\
\hline Others & $\begin{array}{l}\text { Useful space to replace for MY SPACE. } \\
\text { Bring space for date, pressure, weight and height. } \\
\text { Bring the SUPPORT with a full phrase and no acronyms. } \\
\text { Verse of the booklet: bring message of encouragement. }\end{array}$ \\
\hline
\end{tabular}

\section{DISCUSSION}

The elaborate educational booklet had as a proposal to make the reader identify in the character, including in the language. This is a relevant fact, because, often, one does not perceive the use of technical language, which only the professionals of the area understand. Booklets are built to strengthen guidance for family members and patients, and can contribute favorably to the communication process, increase adherence to treatment and decision-making power ${ }^{(8)}$.

The constructed educational material was developed from the identification of the absence of specific material on the excess weight in the adult with hypertension and from the need identified by the researchers of a material that subsidized the orientation and education in health to that specific public. The material produced allowed to give meaning to the dilemmas, doubts and questions of the clientele, favoring the reader to identify himself in the character, contemplating possible solutions.

Validity, in general, refers to the degree to which a tool actually measures the variable it intends to measure. Among the validity types, we highlight the content, which indicates to what extent the tool has an appropriate sample of items to measure the specific construct and adequately cover its domain ${ }^{(9)}$.

Well-designed educational material should support the promotion of critical thinking, clarifying doubts and discourses, rather than reproducing negative representations or suppressing common questions and questions about lifestyle and treatment when one is hypertensive and has excess weight ${ }^{(21)}$.

Regarding the adequacy of the booklet and its validation of appearance, other studies presented adequate or superior category, as occurred in the validation of appearance of a booklet printed for a patient with chronic kidney disease under hemodialysis ${ }^{(22)}$, in which all the participants considered the appearance of the appropriate material, stating that the characteristics and quality of the illustrations contributed to the visualization and perception of the messages contained in the booklet.

It is understood that images that are easy to understand and that portray the reality experienced by the reader, besides holding their attention, insert it in the situation explained, being able to remove it from the comfort zone, beginning the readiness to change behavior, once that the change does not occur from moment to moment, but needs the individual to be willing to change.
However, this process of change does not occur only in the patient-educational interaction. On the contrary, the technology produced aims to be added to the guidance offered by the nurse in the health education process, strengthening and propagating the learning started in an office, so that the individual with hypertension and excess weight can see himself in the character exposed in the material and be willing to begin to reproduce the appropriate conduct that the character claims to follow, reflecting directly on their lifestyle and health condition.

The initial impact is individual, but it is suggested that the success of this impact will lead to the dissemination of good practices among family, friends and acquaintances, reflecting, in the long term, the morbidity and mortality statistics of chronic diseases, with a view to changing the clinical setting current epidemiological.

\section{Study limitations}

The limited number of specialists in the Design and/or Marketing area was considered as a limitation of the study, since the difficulty of returning the contact and returning the evaluation tool.

\section{Contributions to the sectors of Nursing, Health and Public Policy}

The creation and validation of an educational booklet on overweight in adults with hypertension has the contribution of offering complementary technology to the practice of health education for a growing population, given the increase in Noncommunicable Diseases worldwide. This technology aims at the prevention of the disease or associated complications. In addition, the description of the path taken to develop this material may support other studies.

\section{CONCLUSION}

The educational booklet developed for adults with hypertension and overweight was validated in content and appearance by teachers, caregivers and design and/or marketing professionals. The Content Validity Index as well as the material adequacy assessment index reached values considered adequate, making the produced material valid and able to be validated clinically.

It is suggested to carry out the clinical validation of the educational booklet with the target clientele.

\section{REFERENCES}

1. World Health Statistics 2017: monitoring health for the sustainable development goals [Internet]. Geneva: WHO; 2017 [cited 2018 Feb 14]. Available from: http://apps.who.int/iris/bitstream/10665/255336/1/9789241565486-eng.pdf

2. Oliveira GMM, Mendes M, Malachias MVB, Morais J, Moreira Filho O, Coelho AS, et al. [Guidelines for the management of arterial hypertension in primary health care in Portuguese-speaking countries]. Rev Port Cardiol [Internet]. 2017[cited 2018 Feb 14];36(11):789-98. 
Available from: https://doi.org/10.1016/j.repc.2017.10.006 Portuguese.

3. GBD 2015 Risk Factors Collaborators. Global, regional, and national comparative risk assessment of 79 behavioural, environmental and occupational, and metabolic risks or clusters of risks, 1990-2015: a systematic analysis for the Global Burden of Disease Study 2015. Lancet. 2016 Oct 8;388(10053):1659-1724. doi: 10.1016/S0140-6736(16)31679-8. Erratum in: Lancet. 2017 Jan 7;389(10064):e1.

4. NCD Risk Factor Collaboration (NCD-RisC). Worldwide trends in blood pressure from 1975 to 2015: a pooled analysis of 1479 populationbased measurement studies with 19.1 million participants. Lancet. 2017;389(10064):37-55. doi: 10.1016/S0140-6736(16)31919-5.

5. Organização Pan-Americana da Saúde (OPAS), Organização Mundial da Saúde (OMS). Doenças crônicas não transmissíveis causam 16 milhões de mortes prematuras todos os anos [Internet]. Brasilia: PAHO; 2015 [cited 2018 May 31]. Available from: https://www.paho.org/bra/index.php?option=com_content\&view=article\&id=4766:doenc as-cronicas-nao-transmissiveis-causam-16-milhoes-de-mortes-prematuras-todos-os-anos\&ltemid=839

6. Prochaska JO, Velicer WF. The transtheoretical model of health behavior change. Am J Health Promot [Internet]. 1997 [cited 2018 Feb 12];12(1):38-48. Available from: https://www.ncbi.nlm.nih.gov/pubmed/10170434

7. Ryan L, Logsdon MC, McGill S, Stikes R, Senior B, Helinger B, et al. Evaluation of printed health education materials for use by low-education families. J Nurs Scholarsh [Internet]. 2014 [cited 2018 Feb 11];46(4):218-28. Available from: https://doi.org/10.1111/jnu.12076

8. Paula FMS, Beserra NCN, Lopes RCS, Guerra DR. Elaboration of didactic material for processing health products in primary health care units. Rev SOBECC [Internet]. 2017[cited 2018 Mar 01];22(3):165-70. Available from: http://docs.bvsalud.org/biblioref/2017/09/859112/sobecc-v22n3_in_165-170.pdf

9. Polit DF, Beck CT, Hungler BP. Fundamentos de pesquisa em enfermagem. 7th ed. Porto Alegre: Artmed; 2011.670 p.

10. Ministério da Saúde (BR), Secretaria de Atenção à Saúde, Departamento de Atenção Básica. Estratégias para o cuidado da pessoa com doença crônica: hipertensão arterial sistêmica [Internet]. Brasília: Ministério da Saúde; 2013 [cited 2018 Feb 11]. 128 p. Available from: http://bvsms.saude.gov.br/bvs/publicacoes/estrategias_cuidado_pessoa_doenca_cronica.pdf

11. Ministério da Saúde (BR), Secretaria de Atenção à Saúde, Departamento de Atenção Básica. Estratégias para o cuidado da pessoa com doença crônica: obesidade[Internet]. Brasília: Ministério da Saúde; 2014 [cited 2018 Jan 20]. 212 p. Available from: http://bvsms.saude.gov. br/bvs/publicacoes/estrategias_cuidado_doenca_cronica_obesidade_cab38.pdf

12. Ministério da Saúde (BR), Secretaria de Atenção à Saúde, Departamento de Atenção Básica. Estratégias para o cuidado da pessoa com doença crônica [Internet]. Brasília: Ministério da Saúde; 2014 [cited 2018 Jan 22]. 162 p. Available from: http://bvsms.saude.gov.br/bvs/ publicacoes/estrategias_cuidado_pessoa_doenca_cronica_cab35.pdf

13. Associação Brasileira para o Estudo da Obesidade e da Síndrome Metabólica (ABESO). Diretrizes Brasileiras de Obesidade 2016 [Internet]. 4 ed. São Paulo: ABESO; 2016 [cited 2018 Jan 20]. 186 p. Available from: http://www.abeso.org.br/uploads/downloads/92/57fccc403e5da.pdf

14. Malachias MVB, Souza WKSB, Plavnik FL, Rodrigues CIS, Brandão AA, Neves MFT et al. $7^{7}$ Diretriz Brasileira de Hipertensão Arterial. Arq Bras Cardiol [Internet]. 2016 [cited 2018 Feb 11];107(3Supl.3):1-83. Available from: http://publicacoes.cardiol.br/2014/diretrizes/2016/05_ HIPERTENSAO_ARTERIAL.pdf

15. Santiago JCS, Florêncio RS, Moreira TMM. Reflexões sobre o cuidado clínico de enfermagem ao adulto jovem escolar com excesso de peso. In: Moreira TMM (Org.). O cuidado clínico de enfermagem. Fortaleza (CE): EdUECE; 2015. p. 352-62.

16. Arango HG. Bioestatística teórica e computacional. 3rd ed. Rio de Janeiro: Guanabara Koogan; 2009. 460 p.

17. Joventino ES, Oriá MOB, Sawada NO, Ximenes LB. Apparent and content validation of maternal self-efficiency scale for prevention of childhood diarrhea. Rev Lat Am Enfermagem [Internet]. 2013 [cited 2018 Feb 11];21(1):371-9. Available from: http://www.scielo.br/scielo. php?script=sci_arttext\&pid=S0104-11692013000100012\&lng=pt

18. Oliveira MS, Fernandes AFC, Sawada NO. [Educational handbook for self care in women with mastectomies: a validation study]. Texto Contexto Enferm [Internet]. 2008[cited 2018 Jun 01];17(1):115-123. Available from: http://dx.doi.org/10.1590/S0104-07072008000100013 Portuguese.

19. Sousa CS, Turrini RNT, Poveda VB. Translation and Adaptation of the Instrument "Suitability Assessment of Materials" (SAM) into portuguese. Rev UFPE Online[Internet]. 2015[cited 2018 Feb 10]; 9(5):7854-61. Available from: https://periodicos.ufpe.br/revistas/revistaenfermagem/ article/view/10534/11436

20. Pasquali L. Psicometria: teoria dos testes na psicologia e na educação. 5th ed. Petrópolis: Vozes; 2013. 481 p.

21. Góes FSN, Fonseca LMM, Camargo RAA, Oliveira JF, Felipe HF. Educational technology "Anatomy and Vital Signs": Evaluation study of content, appearance and usability. J Med Inform [Internet]. 2015 [cited 2018 Jan 20];84(11):982-987. Available from: https://doi. org/10.1016/j.ijmedinf.2015.06.005

22. Medeiros JRR, Lima MA, Araújo LL, Galiza FT, Felipe GF, Caetano JA. Validation of educational technology for care in hemodialysis. Rev enferm UFPE Online [Internet]. 2016[cited 2018 Feb 11];10(11):3927-34. Available from: https://doi. org/10.5205/1981-8963-v10i11a11474p3927-3934-2016 